\title{
GROUP WORK AS THE WAY OF ORGANISING AND MOTIVATING STUDENTS
}

\section{Shcherbina V.V., PhD in Philology (Kharkiv)}

The article is devoted to the analysis of group work as specific way of organizing students at all the stages of an English lesson. Various kinds of group work are taken into consideration as alternative to the traditional teaching format. They are described as the form of work designed for motivating students, encouraging their active participation, use of imagination, creativity and cooperation between a teacher and learners. It is shown that well-organised group work is the essential component of role playing activities. The types of group format, introduced by N. Mcclver, are taken into consideration. The peculiarities of pair work are revealed. Such group format may be used in groups where there are discipline problems.

Triad group format is analyzed as the alternative to pair work. The role play activities designed for pairs and triads are introduced. It is proved that short role playing exercises can be especially helpful.

Group format Pyramid can be an excellent way of practicing the language of persuasion and having discussion. It is shown that activities of interview type can be successfully organized by means of a pyramid group format. It is proved that in the foreign language classroom interviews are useful because they force students to listen carefully, to practice new grammar structures as well as recycle vocabulary. Interviews give students the opportunity to improve their general knowledge and to be able to communicate on various subjects. Pairs and triads can be easily transformed into group format Pyramid, which requires participation of at least eight students.

It is shown that group format Mingles is considered to be the most challenging and the most effective type of group work. It requires much preparation and greater workload from the teacher. It is proved that Mingles group format is fruitful for advanced learners as activities, organized by means of this format can occupy a lot of time and require acting skills.

The use of all types of group format is aimed at creating relaxed and friendly atmosphere in a foreign language class. It is pointed out that Pyramid and Mingles group formats usually require more preparation than work in pairs and Triads format. Pyramids and Mingles group formats make use of variety of techniques and contribute to the development of group feeling that helps the teacher to motivate students and to create happy learning environment.

(C) Shcherbina V., 2019 
The interactive exercises offered in the article are easily adaptable to different group format and different learners' needs.

Key words: group work, motivation, pair work, teaching format.

Щербина В.В. Групова робота як засіб організації та мотивації студентів. Стаття присвячена аналізу особливостей організації групової роботи студентів на заняттях з іноземної мови. Групова робота розглядається як важливий складник інтерактивних ігор. Проаналізовано види групової роботи, які підвищують мотивацію студентів, сприяють розвитку їх творчих здібностей та уяви. У статті використано класифікацію видів групової роботи, створену Н. Мклвером. Показано, що найбільш поширеним видом групової роботи є робота в парах, яку рекомендовано використовувати в групах, де існують проблеми 3 дисципліною. Тріада, інший різновид групової роботи, розглядається як альтернатива роботи в парах. Tpiady рекомендовано використовувати для невеличких рольових ігор, що не потребують додаткової підготовки. Два інших види групової роботи - Піраміда та Міманина потребують певної додаткової підготовки та передбачають участь не менше ніж восьми студентів. Показано, що використання групового формату Піраміда є найбільш успішним, коли йдеться про рольові ігри 3 організації інтерв'ю. Груповий формат Піраміда також може бути продуктивним під час проведення дискусій за темою заняття. Доведено, що груповий формат Міманина є найбільш складним та водночас найбільш ефективним видом групової роботи. Цей формат потребує більше часу на організацію та проведення. Рольові ігри, організовані за таким форматом, вимагають використання творчих здібностей студентів. Усі види групової роботи $\epsilon$ альтернативою традиційного навчального формату. Вони передбачають використання різноманітних методик навчання іноземної мови, сприяють плідній співпраці, розвитку комунікативної компетенції, надихають та мотивують студентів. Запропоновано низку вправ, які можуть бути легко адаптовані до будь-якого виду групової роботи.

Ключові слова: групова робота, Мішанина, мотивація, навчальний формат, парна робота, Піраміда, Тріада..

Щербина В.В. Групповая работа как способ организации и мотивации студентов. Статья посвящена анализу особенностей организации групповой работы студентов на занятиях по иностранному языку. Групповая работа рассматривается как важная составляющая интерактивных игр. Проанализированы виды групповой работы, повышающие мотивацию студентов, способствующие развитию их творческих способностей и воображения. В статье используется классификация видов групповой работы, созданная Н. Мклвером. Показано, что наиболее распространенным видом групповой работы является работа в парах, которую рекомендуется использовать в группах, где существуют проблемы с дисциплиной. Tриада, другой вид групповой работы, рассматривается как альтернатива работы в 
парах. Триаду рекомендуется использовать для небольших ролевых игр, которые не требуют дополнительной подготовки. Два других вида групповой работы - Пирамида и Мешанина - требуют некоторой дополнительной подготовки и предусматривают участие не менее восьми студентов. Показано, что использование группового формата Пирамида является наиболее успешным, когда речь идет о ролевых играх по организации интервью. Групповой формат Пирамида может также быть продуктивным во время проведения дискуссий по теме занятия. Доказано, что групповой формат Мешанина является наиболее сложным и в то же время эффективным видом групповой работы. Этот формат требует больше времени для организации и проведения. Ролевые игры, организованные в таком формате, требуют использования творческих способностей студентов. Все виды групповой работы являются альтернативой традиционного учебного формата. Они предполагают использование различных методик обучения иностранному языку, способствуют плодотворному сотрудничеству, развитию коммуникативной компетенции, вдохновляют и мотивируют студентов. Предложен ряд упражнений, которые могут быть легко адаптированы к любому виду групповой работы.

Ключевые слова: групповая работа, Мешанина, мотивация, парная работа, Пирамида, Триада, учебный формат.

The topicality of the research. The traditional teaching format, when a teacher is standing in front of the class and telling something, is gradually becoming more and more old-fashioned and unproductive. Such questions as, how to motivate learners, how to keep them involved and active during the whole language class, are asked by all teachers. The problem of learners' motivation is getting especially topical as more and more teachers realize that learners' activity depends on the language material, methods a teacher may use as well as the way learning process is organized. All kinds of group work may become an alternative to the potentially tedious procedure of a teacher's telling something in front of the class. Group work is viewed by many teachers as the essential component of communicative exercises. Group work, properly organized, can give students opportunity to practice language material in more relaxed and unofficial atmosphere. Group work may encourage the kind of students' interaction most teachers are eager to obtain. When students work in groups, no matter big or small, they always have reason for speaking and experiencing the language rather than merely studying it. Group work can both minimize competition and maximize challenge when all the students feel inspired and can do their best. Many linguists regard well-organized group work as the 
important condition of developing learners' creative thinking. A. Maley points out: "Creativity in teaching does not simply happen in a vacuum. We need to create favourable conditions for it" [6: 9]. Group work offers some possibilities that the other teaching formats cannot. Group work may become an excellent way of practicing the language of persuasion, having discussions and developing communicative skills. Working in groups learners can be easier encouraged and motivated. Group work can help the teacher to create a wide range of contexts in which the language seems to be useful and meaningful. All sorts of games for learners of all levels can be organized in groups and enhance students' motivation. Group work organized properly can reveal potential of every student and make every learner contribute to the communicative activity. Group work can be used at the beginning of the lesson, may be suitable for light relief between periods of hard work as well as help the teacher to get students into the right mood before starting on some new project or task. Getting all the students involved into group work is a proper way to achieve classroom goals and improve learners' communicative skills.

The degree of scientific research of the issue. Group work as a kind of language teaching format as well as the component of communicative activities has been the object of research in the studies of many both native and foreign linguists. The research done by D. Hicks, who combines teaching English, with being a writer and teacher trainer, is devoted to peculiarities of group work in mixed ability classrooms. D. Hicks points out that "all classes with more than one student are mixed ability, so in class of 25 or 30 students, there will be a range of abilities, proficiencies, strengths and weaknesses as there is in any group of 25-30 people" [1: 28]. In researcher's opinion, such heterogeneity in the classroom can be overcome by means of wellorganised group work, which can turn weakness of such a situation into strength. D. Hicks points out that in language class divided into groups "may be interesting variations in both speed and achievement depending on variables such as the subject matter of the task, the skills required, the way of working of the task" [1: 28]. D. Hicks emphasizes, that group work may help language learners to realize precisely "where their strengths and weaknesses are in English" [1: 29]. Working in groups, students are able to concentrate mostly on their strengths, go ahead at the same time and make progress. 
N. Mclver, whose experience ranges from teaching English in Europe, designing English courses for hotels, to running summer courses in Britain, works out original ways of group work, which require the active involvement of the learners. The researcher underlines the necessity to change teaching format every twenty minutes and views group work as a very important aspect of teaching. In the article "How do I organize my students into groups" several kinds of group work in a foreign language class were taken into consideration by the researcher. N. Mclver emphasizes the necessity of giving clear instructions in the process of forming groups and reporting back. Analyzing traditional pair work, N. Mclver recommends changing partners as a method which may help "to get more variety into the pair work" [7: 22]. Forming triads or groups of three is viewed as a suitable format for organizing some role-play activities. Pair work format, in N. Mclver`s opinion, can be transformed in more complicated formats, Pyramids and Mingles. N. Mclver points out that these two group formats can be chaotic but at the same time both kinds of group work can be "the most efficient ways of giving everyone maximum language practice in minimum time" [7: 23].

Group activities, created by P. Watcyn-Jones are aimed "at injecting some fun and laughter into foreign language class" [9]. P. WatcynJones pays special attention to such kinds of group work in which students can be more independent as well as work on their own. The teacher is responsible for preparing the material, giving instructions and monitoring progress, made by learners. The teaching techniques, offered by P. Watcyn-Jones, can help to create friendly atmosphere in class, encourage a free flow of ideas and value every student's contribution to role-playing activity.

J. Umstatter designed group activities, aimed at improving students critical thinking. The researcher considers classroom to be "an ideal place to incorporate fun activities” [8:10]. In J. Umstatter's opinion, group work is a "wonderful way to achieve classroom goals and improve language skills" [8: 11].

F. Klippel considers group work to be the basis of dramatizing activities, most of role plays and simulations contain. The way students are organized can be a significant factor of successful class work. In groups properly organized students are likely to remain individual learners as well as to work in a team with other learners. Such group work is aimed at "cooperation and the growth of understanding" [4:7]. 
F. Klippel underlines the necessity of "the pleasant kind of group feeling” which can help to create a relaxed and friendly atmosphere. In his works the linguist takes into consideration the teacher`s role in reducing psychological distance between the teacher and the students which can be obtained by means of using proper ways of organizing students into groups.

J. Hadfield takes into consideration the role of group work in organizing competitive and cooperative games, aimed at developing students' communicative fluency. The activities proposed in his books are based upon the area of foreign language application. J. Hadfield points out that well-organised groups "can provide, in many cases, as much concentrated practice as a traditional drill and, more importantly, they provide an opportunity for real communication” [2: 11]. In J. Hadfield's opinion, group work can help the teacher "to diagnose a student's problem and to take appropriate remedial action".

The aim of this article is to define the role of group work in organizing and motivating students and to offer a set of exercises which can be used for various teaching formats at different stages of the English lesson, aimed at forming and developing students` communicative fluency.

There are many ways of motivating students in the process of forming and developing communicative skills. Group work may function in various forms and may be used at different stages of a foreign language class. Many foreign language teachers consider pair work to be the simplest form of group work as it needs neither additional preparation nor efforts to be organized. If pair work is the only appropriate form of group work, teachers are recommended to change pairs during the same lesson. N. Mclver recommends pair work for classes where there are disciplined problems. There are a great number of activities which can be done in pairs. Let's have a closer look at some of them.The role play Self-directed interview can be easily organized for students working in pairs. Such exercise can be aimed at helping students learn, memorize and recycle enough language material to be able to communicate on various subjects. In this activity each student writes down several questions he would like to be asked. The context of these questions can be either open or restricted to certain grammar or spoken topics. The students interview each other using chosen questions. In this case pair work seems less stressful than working in a bigger group or speaking in front of the whole class. In a 
relaxed atmosphere even shy and reserved students can feel at ease as the interviews don't contain any threatening features. Such activity can run itself as soon as it gets under way. The role play Self-directed interview is also a good way of revision grammar structures and modes. The interview on any subject can become the way of altering the usual learning format and adding variety in everyday classroom routine. Such activities can be used as warming-up exercises as they are easy and fast to organise.

Desert island is one of the most popular ranking activities. In this exercise you may need handout for each pair of students.

Step1: Each pair receives a copy of handout with the list of 25 different objects.

Step2: The teacher explains the task and asks the students to choose the eight most useful items they may be in need on a desert island. It should be taken into consideration that there is food and water on the island but nothing else

Step3: Students work in pairs, rank the items in order of importance and discuss their choice.

Step 4: Students from each pair present their solutions to the whole group, comment on their choice and defend it against the others' arguments.

The list of items can be done by students themselves. This activity is a good way to have fun as the students` choice may seem rather unexpected.

N. Mclver considers group work in Triads to be a good alternative format. The researcher points out that such a structure can help when students "run out of steam in routine class activities, don't understand the structure or run out of ideas working in pairs" [7: 23]. Short role playing exercises can be especially successful when the teacher chooses working in groups of three. Role cards are to be prepared for such a format. The role play Detective work can help to practice grammar structures as well as revise vocabulary connected with the topic Law and order.

Step 1: The teacher prepares the set of cards and the introduction sheet and gives one set of cards to each triad.

Step 2: The teacher asks the students to shuffle the cards and place them face down.

Step 3: The teacher tells the students that a murder was committed last night and the old lady was found dead. She had been hit on the 
head with a frying pan and jewellery was taken from the house. The murder occurred between 7 p.m. and 10.30 p.m. The principal suspect is Ann Brown, the district nurse, who has the key to the old ladies house and lives ten minutes' walk from her house.

Step 4: The cards contain Ann's movements that evening. Two students play the roles of the old lady's neighbours. The third student represents the police. Since the cards have been shuffled, the events will be in a muddled order. The policeman turns up the card from the pile and asking questions tries to restore the probable sequence of events.

Step 5: The triad that manages to reconstruct Ann`s evening correctly and to find out if Ann could have committed the crime, wins.

The role play Tact is a kind of problem-solving activity, aimed at revising topic Family.

Step 1: The teacher prepares cards on which possible family problems are mentioned.

Step 2: The students in each triad are to play the roles of a husband, a wife and a neighbor.

Step 3: The class is arranged so that there are two rows of desks with the free space between them. The husband and wife should be in opposite rows and the neighbor between them standing in the middle.

Step 4: The husband and the wife cannot speak to each other directly. They are to speak to the neighbor, whose task is to relay messages to each of them.

Step 5: When the husband and the wife reach the compromise, the students can change the roles.

The exercise Family budget can be used as a warming up activity as well as the way of recycling vocabulary connected on topic Shopping.

Step 1: The teacher prepares the role cards, representing members of the family. Picture cards should be placed face down in a pile in the middle.

Step 2: The teacher explains that each family has a total of $\$ 500$ to spend. They can spend it as they like but they must come to an agreement.

Step 3: Each member of the family turns up the picture card with certain item on it and tries to prove that this kind of buy is the most essential. The family starts arguing if they need this object or not. If the whole family agrees, the player can keep the card. 
Step 4: The family member who gets the most cards becomes the winner.

Pairs and triads can be easily transformed into Pyramids. N. Mclver considers this kind of group work to be "an excellent way of practicing the language of persuasion and having class discussion" [7: 23]. Students start working in pairs, then pairs get together to continue the activity in groups of four, then groups of four get together as eights. The activity Opinion Poll can be successfully realized in the pyramid.

Step 1: The teacher prepares the list of questions the students are to ask and an interview sheet to write the results of the Opinion Poll. Questions can be adapted to a great number of topics. Students start working in pairs. One of the students asks questions and makes notes of the answers in the interview sheet.

Step 2: Pairs get together in groups of four, presents their results, got in pairs and discuss the answers in a bigger group.

Step 3: Groups of four are united in groups of eight. The students discuss the results they got in groups of four and choose the spokesperson, who reports the results of Opinion Poll to the whole class.

As teaching practice shows, many role playing activities require eight or more students. In this case pyramid can become the ideal group format. The activity Group holiday provides opportunities for intensive speaking practice and can be used for revising topics which have been dealt with in class.

Step 1: The teacher prepares a handout for each student. Each handout contains suggestions for two week holiday they would like to spend together.

Step 2: Students start discussing given suggestions in pairs trying to find out the type of holiday they would like to have.

Step 3: Each pair of students presents their choice to another pair trying to talk them into spending the holiday the way they have chosen.

Step 4: Students go on working in groups of eight. They discuss the choice of each smaller group, outline reasons for their choice and ask questions to comment.

Step 5: The group, whose decision is accepted by the rest of the pyramid, is considered to be the winner.

Many types of language functions and structures can be practiced by means of Mingles group format. N. Mclver considers this format to be "the most chaotic as well as the most efficient type of group work 
which gives every student the opportunity to have maximum language practice" [7: 23]. The activity Guided interviews, offered by F. Klippel, helps the teacher to get every student completely involved.

Step 1: The teacher prepares a handout of the questions and answers. The students are divided into groups. Each group receives either the list of questions or the list of answers.

Step 2: The students start mingling trying to match the questions and the answers.

Step 3: The group which finishes matching first becomes the winner.

The interview topics can vary. The activity can be used as the way of practicing grammar structures, revising vocabulary as well as just having fun at the end of the English class. Some role playing exercises may require additional preparation. The activity The gossip game is aimed at developing students' communicative fluency. It is good for practicing topics Appearance, Personality and relationships.

Step 1: The teacher prepares a role card and a questionnaire for every student and a notes sheet.

Step 2: Each student gets one role card with the description and some personal information about the person he or she is supposed to play. Facts about the neighbours are also given on the card. Some of them are true and some are false.The teacher explains the students that all of them are neighbours and live in the same street.

Step 3: The object of the game is to collect as much information about the neighbor as possible. Students start mingling and spreading information about themselves and their neighbours. If they hear any incorrect rumours about themselves, they should try to correct them and stop the rumours spreading.

Step 4: The teacher asks the students to complete the questionnaire about their neighbours. The student, who manages to correct the false information and stop spreading incorrect rumours, becomes the winner.

This game is designed for advanced learners as it includes a lot of dramatizing and requires acting skills. The activity, in which every student can stand up, move around, interact with many people can be especially motivating.

To sum up, it can be said that any teaching format that differs from a traditional one may be challenging and chaotic. Group work properly organized focuses on students' personalities and help to create the atmosphere of mutual understanding. Group format of any type sets the 
tone of the class and contributes to more effective and exciting learning. F. Klippel underlines, that working in groups students learn "to use their knowledge of the foreign language flexibly" [4: 7]. Group work can help the teacher to prepare students for all communicative situations that may arise. The learners` interest and motivation can be aroused by involving into group work. Group work properly organized can reduce the psychological distance between the students and the teacher and help to create learning environment, which leads students to success and joy of learning.

The further research in this area is to be devoted to the analysis of dramatizing activities as the way of encouraging and motivating students.

\section{LITERATURE.}

1. Hicks D. Mixed Ability classrooms. Turning weakness into strength. Іноземні мови. Київ: 2001. № 2. С. 28-29.

2. Hadfield J. Classroom Dynamics. Oxford: Oxford University Press, 2006. $128 \mathrm{p}$.

3. Johnson S. Where Good Ideas Come From. Cambridge: Cambridge University, 2016. 236 p.

4. Klippel F. Keep Talking. Cambridge: Cambridge University Press, 1984. $202 \mathrm{p}$.

5. Lee W. Language Teaching Games and Contests. Oxford: Oxford University Press, 2000. 145 p.

6. Maley A. Creativity in the English Language Classroom / ed. N. Peachy. London: British Council, 2015. 170 p.

7. Mclver N. How do I organize my students into groups. Іноземні мови. 2001. № 4. C. 22-23.

8. Umstatter J. English Brainstormers. San Francisco: A Wiley Imprint, 2006. $378 \mathrm{p}$.

9. Watcyn-Jones P. Fun Class Activities. London: Penguin Book, 2000. $235 \mathrm{p}$.

\section{REFERENCES}

Hicks, D. (2001). Mixed Ability classrooms. Turning weakness into strength. Inozemni movy [Foreign languages]. Kyiv: Inozemni Movy, 2, pp. 28-29 [in English]. 
Hadfield, J. (2006). Classroom Dynamics. Cambridge: Cambridge University Press [in English].

Johnson, S. (2016). Where Good Ideas Come From. Cambridge: Cambridge University Press [in English].

Klippel, F. (1984). Keep Talking. Cambridge: Cambridge University Press [in English].

Lee, W. (1980). Language Teaching Games and Contests. Oxford: Oxford University Press [in English].

Maley, A. (2015). Creativity in the English Language Classroom. Peachy, N. (Ed.). London: British Council [in English].

Mclver, N. (2001). How do I organize my students into groups. Kyiv: Inozemni movy [Foreign languages], 4, pp. 22-23 [in English].

Umstatter, J. (2002). English Brainstormers. San Francisco: A Wiley Imprint [in English].

Watcyn-Jones, P. (2000). Fun Class Activities. London: Penguin Book [in English].

Стаття надійшла до редакиії: 17.02.2019

Щербина Вікторія Володимирівна, канд. філол. наук, доцент кафедри філології, перекладу та мовної комунікації Національної академії Національної гвардії України (61001, Харків, майдан Захисників України, 3), e-mail: independent2014@ukr.net; orcid: http:// orcid.org/0000-0002-2717-3855.

Щербина Виктория Владимировна, канд. филол. наук, доцент кафедры филологии, перевода и языковой коммуникации Национальной академии Национальной гвардии Украины (61001, Харьков, площадь Защитников Украины, 3), e-mail: independent2014@ukr.net; orcid: http:// orcid.org/0000-0002-2717-3855. Victoria Shcherbina, $\mathrm{PhD}$ in Philology, Associate Professor, Department of Philology, Translation and Lingual Communication, National Academy of the National Guard of Ukraine (61001, Kharkiv, 3 Zakhysnykiv Ukrainy square), e-mail: independent2014@ukr.net; orcid: http:// orcid.org/00000002-2717-3855. 